\title{
Korkeakoulujen keskityttävä tieteellisyyteen
}

\begin{abstract}
Heinonen, Arto \& Mäkelä, Keijo. 1981. Korkeakoulujen keskityttävä tieteellisyyteen. Aikuiskasvatus 1, 3-4, 102-104. - Artikkelin lähtökohtana on valmistunut Avoimen korkeakoulun toimikunnan mietintö. Kirjoittajat näkevät, että mietinnössä ei ole riittävästi selvitetty avoimen korkeakouluopetuksen tarvetta eikä se anna riittävää pohjaa tasa-arvopyrkimysten toteutumiselle. Korkeakouluopetus voi tapahtua vain tieteellisessä ilmapiirissä, tiedeyhteisössä, joka rakentuu tutkimukselle. Artikkelissa on myös kuvattu laajemmin korkeakoulujen asemaa aikuiskoulutuksessa.
\end{abstract}

Maamme korkeakouluopetuksen laajentamisen perinteet ulottuvat aina 1870-luvulle saakka. Tällöin yliopiston opettajat pitivät yliopiston ulkopuolisille, pääasiassa naisille tarkoitettuja luentoja. Yliopiston avoimmuutta vaadittiin vetoamalla lahjakkuusreserveihin.

Nyt, sata vuotta myöhemmin kaikille lahjakkaille nuorille ollaan antamassa tilaisuus korkeakouluopintoihin. Keskiasteen uudistuksella turvataan ammatillisen koulutuksen saaneiden mahdollisuudet akateemisuuteen. Viime vuosina ylioppilastutkintoa suorittamattomille on varattu 5-20\% korkeakoulujen aloituspaikoista. Toisaalta likipitäen joka toinen ikäluokkansa nuori kirjoittaa ylioppilaaksi.

Keskustelı onkin suunnattu aikuiskoulutukseen. Koulutus on merkittävä apu kehittäessä yhteiskuntaa tai yksilön suunnitellessa omaa elämäänsä. Erityisesti tieteellisen tiedon ymmärtámiseen on syytä kiinnittää huomiota. Jatkuvasta koulutuksesta on tullut yhteiskuntapolitiikkamme keskeinen väline.

Avoimen korkeakoulun toimikunta on saanut valmiiksi mietintönsä, jossa pyritään löytämään keinot koulu- ja nuorisoiän ohittaneiden opiskelulle. Tavoitteena on avoin korkeakoulu, joka pystyy opettamaan tieteellistä ajattelutapaa sekä tiedon hankinnan ja luomisen taitoa. Avoimessa korkeakoulussa saisi opiskella pääsääntöisesti jokainen 25 vuotta täyttänyt.

Ajatus avoimesta korkeakoulusta on hyvä. Tieteestä ei ole hyötyä, jollei tieto leviä laajalle. Avoin korkeakoulu poistaa myös koulutuksen umpiperät. Avoimen korkeakoulun kehittämiselle löytyy varmasti muitakin perusteita. Käytännössä kuitenkin avoimen korkeakoulun tyyppiopiskelija on alle 30 -vuotias ylioppilastutkinnon suorittanut nainen. Tämän ovat avoimen korkeakoulun kokeilut osoittaneet.

Avoimen korkeakoulun toimikunta ei ole selvittänyt koulutuksen kysyntää eikä sen määräytymistä. Maahamme on luotu varsin mittava korkeakoulujärjestelmä, jonka pitäisi kouluttaa 1980-luvun lopulla $20 \%$ ikäluokasta. Esimerkiksi Ruotsin korkeakouluissa ei ole kaikkia aloituspaikkoja saatu täytetyksi. Tällä hetkellä avoimen korkeakoulun ja kesäyliopistojen ohjelmaan voi kuulua sienikursseja perheenäideille sekä kieliopintoja, joiden opiskelijat ovat etupäässä abiturienttejä. Varsinaisen avoimen korkeakouluopetuksen todellinen tarve maassamme olisikin pikaisesti selvitettävä.

Avoimessa korkeakoulussa opiskelun pitäisi olla periaatteessa itseisarvoista. Sen ei tulisi tähdätä tutkintoon, vaan pyrkimyksenä olisi saavuttaa korkeakoulutasoisia valmiuksia. Perustutkinnon suorittamisoikeus tosin voitaisiin avoimen korkeakoulun opiskelijalle antaa suhteellisen helposti. Opetuksen tulisi motivoida opiskelua. Korkeatasoisella opetuksella riittäisi kuulijoita. Tämä kontrolloisi samalla opetuksen tasoa.

Avoimen korkeakoulun toimikunta on kuitenkin ehdottanut omaa tutkintojärjestelmää: vastikään poistetut alemmat korkeakoulututkinnot takaisin. Tutkinnonuudistuksella selkeytetty tutkintojärjestelmä aiotaan sekoittaa jälleen. Opiskelusta tulee helposti muodollista, tutkinnon mekaanista suorittamista. Tämä myös lisää tarpeettomasti koulutuksen kysyntää. 
Suunnitelmien mukaan avoimessa korkeakoulussa opetus tapahtuisi pääosin varsinaisten korkeakoulujen ulkopuolella. Opettajakunta muodostuisi korkeakoulujen vakinaisista opettajista, kansalais- ja työväenopistojen opettajista sekä muista korkeakoulututkinnon suorittaneista henkilöistä. Avointa korkeakoulua varten ei ole tarkoitus luoda erillisorganisaatiota, vaan aikuisille suunnattua korkeakouluopetusta annettaisiin nykyisissä oppilaitoksissa ja etäopetuksen välityksellä. Korkeakoulut toimisivat avoimen korkeakoulun keskuksina, jotka johtaisivat alueellista toimintaa. Oppilaat olisivat pelkästään tietoa saavana osapuolena. Tieteellistä ilmapiiriä ei olisi, koulukunnista puhumattakaan.

Tiedeyhteisö on tieteen kehitykselle välttämätön. Käytännössä korkeakouluopetusta voidaan antaa vain varsinaisissa korkeakouluissa. Näiden ulkopuolella pidetyt luennot, seminaarit tai harjoitukset eivät synnytä tiedeyhteisöjä. Tämän vuoksi opiskelijoiden on tultava korkeakouluihin. Tätä vaatii tieteen henki, kuten myös tietokoneet, laboratoriot ja kielistudiot.

Korkeakouluopetus perustuu tutkimukseen. Näin ollen avoimen korkeakoulun opetus pitäisi olla täsmälleen samaa kuin tutkinto-opetus. Tätä periaatetta tulisi soveltaa myös korkeakoulutasoisen täydennyskoulutuksen järjestelmissä. Tämä säästää myös tieteellisiä resursseja opetuksen suunnittelusta varsinaiseen tutkimukseen. Erityisesti uudet korkeakoulut tarvitsevat tiedeyhteisönsä kehittämiseen kaikki niukat resurssinsa. Avoimen korkeakoulun toimikunta ehdottaa suunniteltavaksi helppotajuisia opetuspaketteja aikuisopiskelijoille. Pintatiedon jakamista korkeakouluopetuksena on kartettava. Korkeakoulutuksessa laadusta ei voida tinkiä.

Avoimen korkeakoulun ja täydennyskoulutuksen sisällyttäminen nykyisien perus- ja jatkotutkintojen osiksi vaatii kuitenkin tutkintoon tähtäävän opetuksen voimakasta kehittämistä. Tutkinnoista puuttuu useasti yleissivistävä ja kasvatuksellinen luonne. Samoin opetus on irrallaan korkeakoulua ympäröivästä todellisuudesta, monasti vieläpä tieteestäkin. Nämä ovat luultavasti viime kädessä syitä, jotka vaikuttivat ehdotukseen avoimen korkeakouluopetuksen irrottamisesta tutkintoopetuksesta. Yleisessä korkeakoululaitoksen kehittämisvimmassa on unohtunut tärkein: tutkintojen laadullinen kehittäminen.
Ongelma avoimessa korkeakoulussa on jako pehmeisiin ja koviin tieteisiin. Suunnitelmien mukaan humanistiset ja yhteiskunnalliset tieteet ovat etusijalla opetuksessa. Opetuksen rajoittuessa pehmeisiin tieteisiin kovasta tieteestä tulee vaivattomasti yläluokka. Diplomi-insinöörejä ja lääkäreitä kyllä arvostettaisiin, muiden korkeakoulututkinnon suorittaneiden arvostus ei olisi ylioppilasta kummempi. Avoimen korkeakoulun tasa-arvopyrkimykset näyttävät nykyisellään näennäisiltä.

Tieteellistä tietoa voisi levittää radion ja television avulla. Samoin maamme 270 kansalais- ja työväenopistoa voisivat antaa opetusta, joka vastaisi lähinnä korkeakoulututkintoihin liittyviä yleisopintoja. Mitään varsinaista yhteyttä itse korkeakoululaitokseen ei olisi. Opetusta ei myöskään arvioitaisi, olisiko se korkeakoulutasoista vai ei.

Opiskelu kansalais- ja työväenopistoissa tulisi olla tavoitteiltaan lähinnä harrastusta samoin kuin avoimessa korkeakoulussa. Kesäyliopistot, joiden opetus on suuntautumassa entistä voimakkaammin jokapäiväisiin askareihin, voisivat liittyä kansalais- ja työväenopistojen organisaatioihin. Vastaavasti varsinaisille korkeakouluille luotaisiin kolmas lukukausi kesäksi. Kansalais- ja työväenopistot olisivat mukana kehittämässä etäopetusta yhdessä Yleisradion kanssa.

Avoimella korkeakoululla sekä kansalais- ja työväenopistoilla on yleissivistävä luonne. Näiden rinnalla annettaisiin täydennys- ja työllisyyskoulutusta. Korkeakoulujen täydennyskoulutuskeskusten pitäisi toimia varsinaisesta korkeakoulutuksesta irrallaan, pikemminkin yhteydessä muiden täydennyskoulutusta antavien yksikköjen kanssa. Täydennys- ja työllisyyskoulutusta voitaisiin antaa myös muualla vastaavasti kuten annetaan yleissivistävää koulutusta kansalais- ja työväenopistoissa.

Avoimen korkeakoulun toimikunnan esitys lienee lähellä korkeakoulujen ajatuksia. Toimikunnan mietinnön mukaan avoimen korkeakoulun kehittäminen on osa korkeakoululaitosta ja kuuluu sen kehittämissuunnitelmiin. Tutkinto-opetuksesta erotettu avoin korkeakoulu on ainoastaan korkeakoulujen määrällisten kasvupyrkimysten toteuttaja. Tiede on siinä sivussa unohtunut.

Jatkuvan koulutuksen idea on kannatettava. Tieteestä viime kädessä huolehtiva tutkintoihin perustuva järjestelmä on kuitenkin pidettävä selkeänä. Avoimen korkeakoulun kehittämistoimenpiteet eivät saa häiritä varsinaista korkeakouluopetusta. 


\section{Kuviot}

\section{Korkeakoulujen asema aikuiskoulutuksessa}

Avoimen korkeakoulun toimikunnan ehdotuksiin ja myös nykytilannetta kuvaava aikuis- koulutuksen järjestelmä on esitetty kuviossa 1. Avoimen korkeakoulutuksen ja korkeakoulujen täydennyskoulutuksen tulisi aina olla jokin osa perus- tai jatkotutkinto-opetusta oheisen artikkelin ja kuvion 2 mukaisesti.

Kuvio 1: Eri koulutusmuotojen suhteet Avoimen korkeakoulun toimikunnan ehdotuksista pelkistettynä. Korkeakoulutuksella ei ole tällöin erikoisasemaa. Eri koulutusmuotojen väliset rajat ovat koulutuksen sisällön, voimavarojen ja organisaation suhteen hämärtyneet ja sekavat.

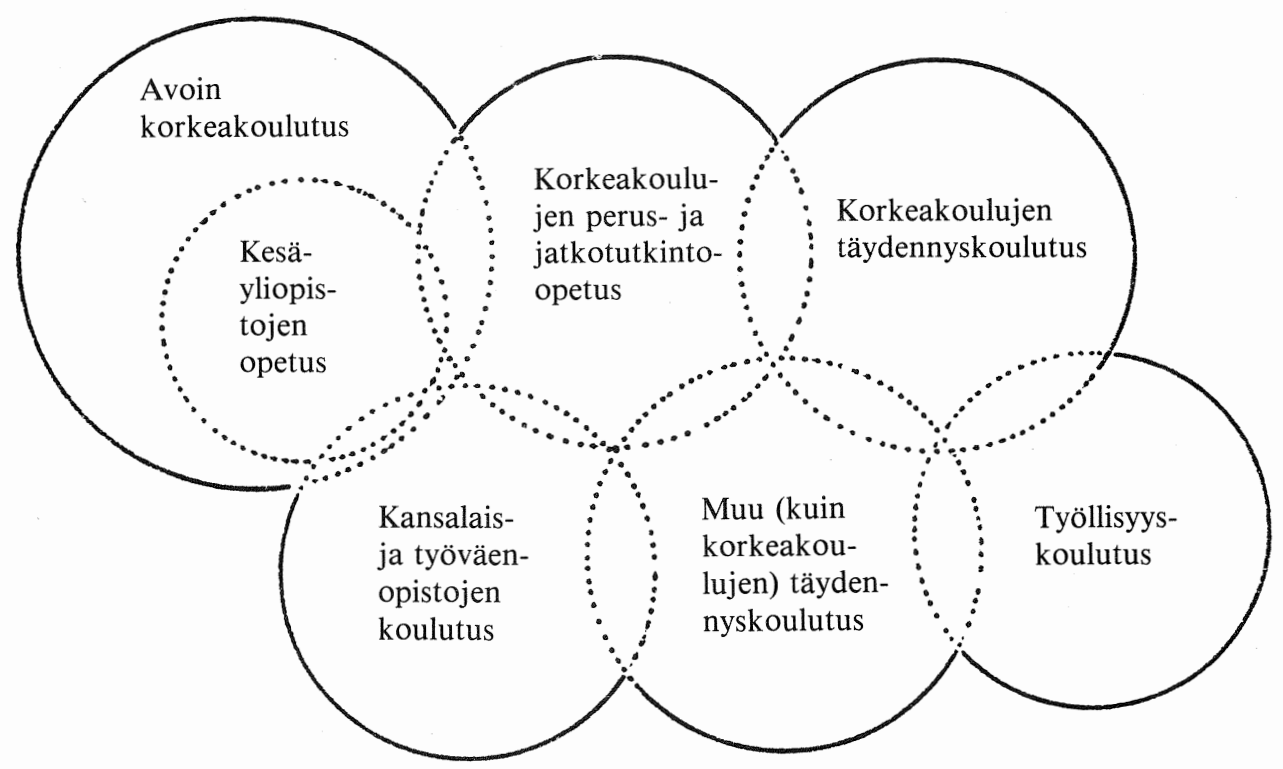

Kuvio 2: Eri koulutusmuotojen suhteet oheisen artikkelin esitysten mukaisesti. Järjestelmässä on turvattu tieteellisestä tiedosta viime kädessä vastaavalle koulutukselle (a) erikoisasema. Muista tarpeista lähtevä koulutus (b) on eriytetty korkeakoulutuksesta koulutuksen sisällön, voimavarojen ja organisaation suhteen.

a)

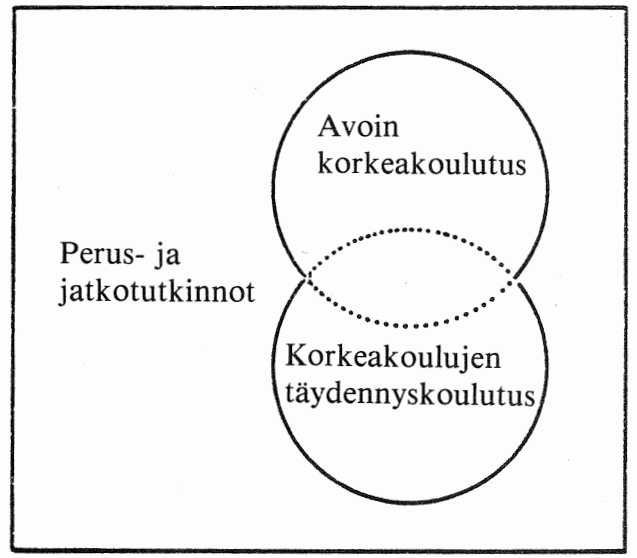

b)

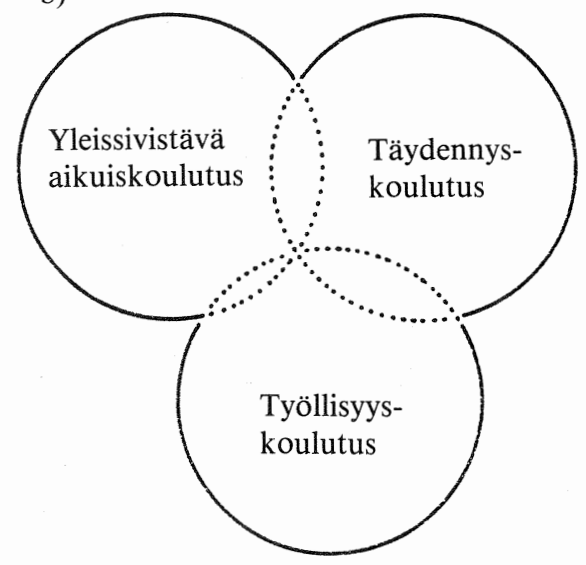

